\title{
Use of Internet for Innovation Management by Extension Agents in Oyo State
} Http://dx.doi.org/10.4314/jae.v20i1.8

\author{
Aromolaran, A. K. \\ Department of Agricultural Extension and Rural Development \\ Federal University of Agriculture Abeokuta \\ E-mail:garomolaran@yahoo.com \\ Phone: 08034878508
}

\section{Alarima, C. I.}

Department of Agricultural Extension and Rural Development Federal University of Agriculture Abeokuta

E-mail: corneliusalarima@gmail.com

Phone: 07019296171

\section{Akerele, D.}

Department of Agricultural Economics and Farm Management

Federal University of Agriculture Abeokuta

E-mail: dareakerele@yahoo.co.uk

Phone: 07037957280

\section{Oyekunle, 0.}

Agricultural Media Resources and Extension Centre

Federal University of Agriculture Abeokuta

E-mail: lekbidoye@yahoo.com

Phone: 08035086059

\section{Leramo, G. A.}

Department of Agricultural Extension and Rural Development

Federal University of Agriculture Abeokuta

E-mail: roggerggregor@gmail.com

Phone: 08144978371

\section{Abstracts}

This study examined extension agents' perception of the use of the Internet for sourcing and disseminating agricultural innovation in Oyo state. Simple random sampling technique was used to select 80 respondents. Data collected with a questionnaire were subjected to descriptive and Pearson product moment correlation analysis. Findings reveal that mean income, age, and working experience of respondents were $\$ 341,890,39$ years and 11 years, respectively. The Internet was extensively used by 47.5 percent of the respondents, and $51.2 \%$ accessed the Internet with their mobile phones. Information sourced included responses to farmers' feedback (76.2\%) and better 
Creative commons User License: CC BY-NC-ND

Abstracted by: EBSCOhost, Electronic Journals Service (EJS),

Google Scholar, Directory of Open Access Journals (DOAJ),

Journal Seek, Scientific Commons,

Food and Agricultural Organization (FAO), andCABI
Journal of Agricultural Extension

Vol. 20 (1) June, 2016

ISSN(e): 24086851; ISSN(Print); 1119944X

http://journal.aesonnigeria.org

http://www.ajol.info/index.php/iae

Email: editorinchief@aesonnigeria.org

dissemination techniques (72.5\%). Many (56.2\%) perceived use of Internet positively. A significant relationship existed between extent of use and perception of Internet use for innovation management $(r=0.231 p<0.05)$. It is therefore recommended that extension agencies should provide facilities to increase Internet access for extension agents and re-orientate them on better use of the Internet for sourcing and disseminating of innovation in order to sustain extension system for agricultural transformation.

Keywords: Innovation management, extension services, and Internet use

\section{Introduction}

In Nigeria, the use of Internet is becoming dominant among the literate to access timely, accurate and relevant information (Nkanu \& Okon 2010). Internet platform can be used by extension agents to seek new ideas that could be useful to their clientele. Salau and Saingbe, (2008) opined that frontline extension workers, who are the direct link between farmers and other stakeholders in the agricultural knowledge transfer and information management system should be well positioned to make use of information communication technologies (ICT) to access expert knowledge and other types of information that could be beneficial to farmers. As a result of the numerous information resources on the Internet and increasing investment in the provision of Internet services and resources, it is essential that extension services and farmers should be enabled to have better access to innovations. It will be fascinating if the farmers and extension agents can use the Internet to access and exchange new ideas. This could enhance the extension service delivery thereby improving farmers' knowledge of agricultural technologies and better their attitudes towards innovation adoption. Aker (2010) opines that so far there is no large survey and data-based study on the impact of ICT on extension services in remote areas. This is probably due to lack of reliable data on outcome variables, as well as variations across extension and non-extension communities; and between users and non-users in observable and unobservable. The use of information stored on the Internet to find accurate and reliable information will be a new form of literacy to farmers and probably to extension agents as well. Whitworth, (2009) defines "information literate" as a person who can recognize when information is needed and be able to locate, evaluate and use effectively the needed information.

To become fully literate in today's world, farmers, as well as the change agents, must become proficient in the literacy of ICT. It is believed that Internet is fast, versatile and readily available in as much as there are gadgets and facilities to connect into. In recent years, some ICT devices such as phones have been introduced as a means of accessing Internet to source and disseminate innovations. It is faster but extension services still adhere to old extension methods of contacts which have been individual and group methods that result in a delay in feedbacks. Internet is a fast means of disseminating innovation to farmers and obtaining quick feedbacks. Internet could be used by extension agents to manage innovation transfers within extension system. It is imperative to examine perception of the extension workers on the use of Internet to 
Creative commons User License: CC BY-NC-ND

Abstracted by: EBSCOhost, Electronic Journals Service (EJS),

Google Scholar, Directory of Open Access Journals (DOAJ),

Journal Seek, Scientific Commons,

Food and Agricultural Organization (FAO), andCABI
Journal of Agricultural Extension

Vol. 20 (1) June, 2016

ISSN(e): 24086851; ISSN(Print); 1119944X

http://journal.aesonnigeria.org

http://www.ajol.info/index.php/iae

Email: editorinchief@aesonnigeria.org

source and disseminate agricultural innovation. Therefore, this study specifically examines the following objectives: 1. extent of extension agents' use of the Internet in sourcing and disseminating agricultural innovation; 2. specific information sourced from the Internet by extension agents; 3. devices used to access Internet by extension agents; 4. extension agents' perception of use of Internet for sourcing and disseminating agricultural innovation; 5 . challenges associated with the use of Internet for agricultural innovation sourcing and dissemination. The hypothesis of the study is stated, thus, there is no significant relationship between the extent of Internet use for innovation management (sourcing and disseminating) by extension agents and their perception towards it.

\section{Methodology}

\section{Study Area}

The study was conducted in Oyo State. Oyo State is one of the six states in the southwestern geopolitical zone of Nigeria. Oyo State comprises of 33 local government areas (LGAs) and has a land mass of about 27,249 square kilometres. Its population is estimated at 6,617,720 in 2007 (NPC, 2007). Oyo State has an equatorial climate with dry and wet seasons and relatively high humidity. An average annual rainfall is between $800 \mathrm{~mm}$ and $1500 \mathrm{~mm}$ while average daily temperature ranges between $25^{\circ} \mathrm{C}$ and $35^{\circ} \mathrm{C}$, almost throughout the year. The vegetation pattern of Oyo State is that of rain forest in the south and guinea savannah in the north. Thick forest in the south gives way to grassland interspersed with trees in the north.

\section{Sampling procedure and data collection}

A multistage sampling procedure was used to select the respondents. Out of the four (4) ADP zones in the state, two were randomly selected; eight (8) blocks were selected from each zones using a simple random method to make 16 blocks after which five cells were selected from each of the blocks. One extension agent each from the cells was selected to make a total of 80 extension agents that were sampled for the study. Data were collected through the use of structured questionnaire.

\section{Measurement of variables}

Some of the main variables measured for the study were: (a) Extent of Internet use by extension agents which was measured with a scale of three points consisting ten items. It ranged from always, occasionally and never, which were assigned 3, 2 and 1 , respectively. (b) Perception of extension agents towards the use of Internet for innovation management was measured using a five-point Likert-type scale of strongly agree, agree, undecided, disagree and strongly disagree, which were assigned a score of 5 to 1 , respectively from which mean perception score was obtained. 


\section{Data analysis}

Descriptive statistics used were frequency counts, mean and percentages to describe the characteristics of respondents. The inferential statistical tool used to test the hypothesis was Pearson product moment correlation.

\section{Results and Discussion}

\section{Socio-economic Characteristics of Respondents}

Table 1 shows that the mean age of respondents was 39 years. According to Umar, et al (2013), many of the extension agents are young and active. Most $(67.5 \%)$ of them had Bachelor degree while one-third (31.2\%) had Higher National Diploma. This is an indication that many of the respondents are educated and that could contribute to their comprehension of the Internet thereby increasing the likelihood of Internet use in the study area. This finding corroborates Adetumbi, et al (2013) who opine that the use of the Internet is influenced by the level of education of extension agents.

\section{Table 1: Socio-economic characteristics of extension agent}

\begin{tabular}{lll}
\hline Variables & Mean & Percentage \\
\hline $\begin{array}{l}\text { Age (years) } \\
\text { Sex }\end{array}$ & 39 years & $50 \%$ (Male) \\
$\begin{array}{l}\text { Marital status } \\
\text { Work experience (years) }\end{array}$ & 11 years & $91.2 \%$ (Married) \\
Level of Education & 4 persons & $67.5 \%$ (B.Sc.) \\
Household Size & 341,980 & \\
Income per annum & & \\
\hline
\end{tabular}

Table 1 show that the average year of experience of the respondents was 11 years; this implies that many of the extension agents are relatively established in their profession and they could be more confident at trying a new approach in their profession. The respondents earned an average of 341,980 per annum. Fund is an important factor in the use of Internet because money is required in subscribing for Internet where it is not readily available in the offices. Even when Internet is available, there are some fees that must be paid to access some information on the Internet and this is a function of money. Therefore, the amount the respondents earned can affect how they use the Internet.

\section{Extent of Internet use for Innovation Sourcing and Disseminating}

Figure 1 shows that only 47 percent of the extension agents extensively use the Internet to source and disseminate innovation. This implies that more than half of the respondents are not extensively using the Internet. Despite a large number of 
Creative commons User License: CC BY-NC-ND

Abstracted by: EBSCOhost, Electronic Journals Service (EJS), Google Scholar, Directory of Open Access Journals (DOAJ), Journal Seek, Scientific Commons,

Food and Agricultural Organization (FAO), andCABI
Journal of Agricultural Extension

Vol. 20 (1) June, 2016

ISSN(e): 24086851; ISSN(Print); 1119944X

http://journal.aesonnigeria.org

http://www.ajol.info/index.php/jae

Email: editorinchief@aesonnigeria.org

agricultural information on the Internet and the opportunity of accessing Internet via phone by farmers, only a few of the extension agents uses it for the purpose of sourcing and dissemination of innovation. Saravanan (2008) asserts that Internet cafes are increasing in numbers but not many extension agents and farmers use it to search for information. Entries in Table 2 show that majority $(72.5 \%)$ often use the Internet to source for innovations occasionally. More than half $(53.8 \%)$ occasionally lost track of time when they are using the Internet. Above 50 percent of the respondents used Internet to source agricultural news and interact with their colleagues while (38.8\%) always use it for communicating with extension agents in other countries on improved technologies. Adetumbi et al (2013) report that the use of Internet was not popular among extension agents in performing their job. Internet was ranked sixth among nine ICT devices but it was found that the Internet was the most constrained ICT by such factors as; lack of infrastructure facilities, poor connectivity, low technical know- how and so on.

Table 2: Distribution of extension agents by their extent of Internet's use in Oyo State

\begin{tabular}{lll}
\hline Statements & Mean & SD \\
\hline I often use the Internet to source for innovations & 2.28 & 0.45 \\
I deliberately restricted my Internet usage due to previously excessive use & 1.69 & 0.77 \\
I always lost track of time when am using the Internet & 1.76 & 0.64 \\
The use of Internet enables me in communicating with an extension agent in another & 2.01 & 0.78 \\
country on improved technologies & & \\
I use Internet in communicating with colleagues on recent innovations & 2.48 & 0.69 \\
I frequently use Internet in sourcing for agricultural news & 2.55 & 0.50 \\
Through the use of Internet am able to source for research- based information & 2.43 & 0.49 \\
I use Internet to send videos and images of improved technologies to other extension & 1.98 & 0.76 \\
agent and farmers & & \\
I always use Internet to disseminate ideas to farmers organizations & 1.73 & 0.77 \\
I use Internet in sourcing for information while preparing for presentation & 2.16 & 0.51 \\
& & \\
\hline
\end{tabular}
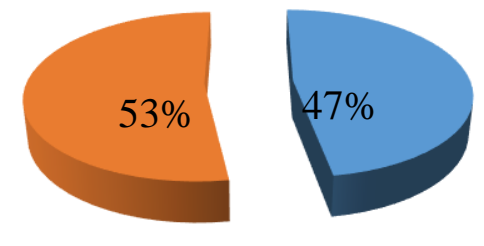

Extensive Usage

$\square$ Not Extensive Usage

Figure 1: Overall Internet's use by extension agent in the study area

\section{Information sourced from the Internet}

Table 3 shows the information sourced from the Internet by extension agents. Most $(81.2 \%)$ of the respondents sourced marketlocation to aid the sale of farmers' 
Creative commons User License: CC BY-NC-ND Abstracted by: EBSCOhost, Electronic Journals Service (EJS), Google Scholar, Directory of Open Access Journals (DOAJ), Journal Seek, Scientific Commons,

Food and Agricultural Organization (FAO), andCABI
Journal of Agricultural Extension Vol. 20 (1) June, 2016

ISSN(e): 24086851; ISSN(Print); 1119944X http://journal.aesonnigeria.org http://www.ajol.info/index.php/iae Email: editorinchief@aesonnigeria.org

produce while 77.5 percent of the respondents sourced information on the current price of agricultural produce. Aina (2002) opines that ICTs have enhanced effective dissemination and efficient access to scientific, technical and marketing information which are previously difficult and expensive. Likewise, more than 70 percent of the respondents sourced clarifications on certain issues from farmers' feedback, better and new methods of disseminating innovation as well as current challenges faced by farmers.

Table 3: Information sourced from the Internet in Oyo State

\begin{tabular}{ll}
\hline Information sourced & $\%$ \\
\hline Current price of agricultural produces & 77.5 \\
Market location 's to help farmers sell produce & 81.2 \\
Information on how best to disseminate innovations to farmers & 72.5 \\
Information's on current challenges being faced by farmers & 71.2 \\
Clarifications on certain issues from farmers feedback & 76.2 \\
Extension agent source for information on farmer's livelihood and & 65.0 \\
possible ways of improving their living standards & 63.8 \\
\hline Information on another source of income for the farmers &
\end{tabular}

\section{Source: Field Survey, 2015.}

None of the information sourced by respondents is less than 50 percent. Even though multiple responses were recorded, more than half of the extension workers are likely to seek for information around the issue listed in Table 3. This implies that it is only this subject that will interest extension workers more when it comes to the use of the Internet for sourcing and disseminating of innovation. Ezeh (2013) reports that extension agents with the use of the Internet can access and source for varieties of information that could benefit farmers and also improve their extension services delivery.

\section{Devices Used to Access Internet by Extension Agents}

Figure 2 shows the distribution of extension agents based on the devices they were using in sourcing and disseminating information on the Internet. It reveals that many $(51.2 \%)$ of the respondents use mobile phones as a device to access the Internet, while less than half (48.8\%) use a computer to access it. This could be because a phone is readily available with the extension agents, handy and mobile. It can easily be carried about unlike the computer either laptops or desktop. Mobile computing, via smartphones and tablets, is a technology with considerable potential for Extension agencies and clientele. Fifty-eight percent of all adults have smartphones, and $63 \%$ use their phones to access the Internet, with mobile Internet usage as high as $85 \%$ for adults under 30 (Pew Research, 2014; Duggan \& Smith, 2013). According to the finding of this study more extension agents use a mobile phone to access the Internet, therefore, it will be worthwhile to provide either a mobile phone or any 
Internet supported handy and mobile device for them which carried to the field to aid their service delivery. Jones, Doll \& Taylor (2014) opined that mobile phones and tablets have become important tools for accessing information on the Web, it was reported also that visitors to The Almond Doctor Extension blog and AgFax.com are increasingly using smartphones and tablets rather than desktop computers.

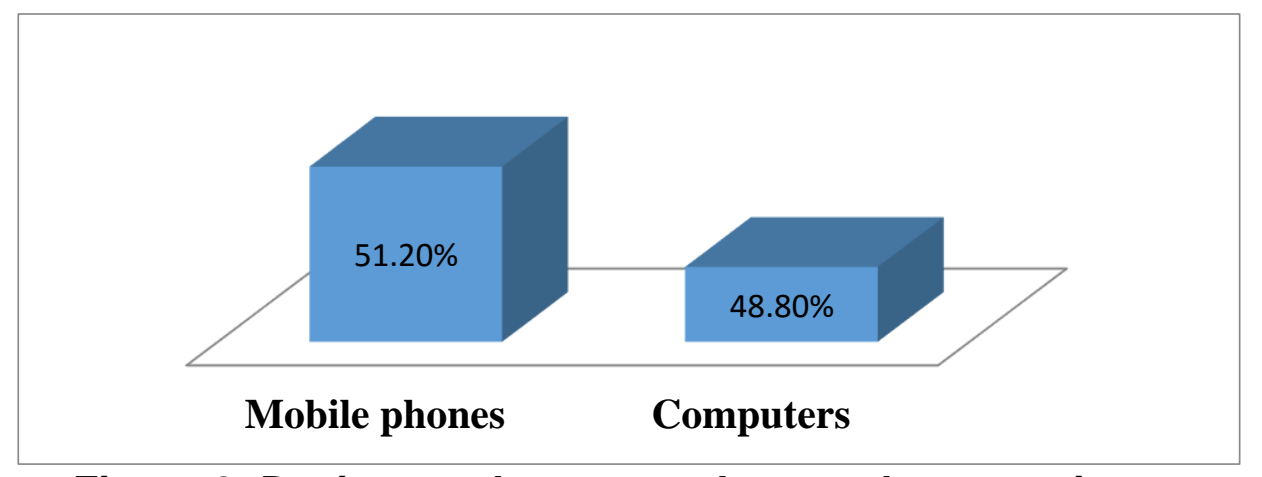

Figure 2: Device used to access Internet by extension agents

\section{Extension agents' Perception on the Use of Internet for Innovation Management}

Figure 3 shows the overall perception of the extension workers on the use of Internet for sourcing and disseminating innovations. More than half $(56.20 \%)$ of the respondents had a favourable perception of the use of the Internet, this implies that with the provision of facilities and access to Internet extension agents may be willing to utilize Internet to improve their extension service delivery. The efficiency of the extension service achieved by the use of Internet will make innovations get to farmers faster and it has a way of reflecting in the transformation of the agriculture. According to Danladi et al., (2008), ICT is considered of great importance to mankind and among the notable areas include; time-saving, increased efficiency, saves energy, process, and store and transfer relevant information. In the same line, Mugo and Vermeulen (2011) opined that ICTs can help to promote agricultural production. Table 4 shows the distribution of extension agents according to their perception towards the use of the Internet for extension services delivery. Many (88.7\%) of them were of the opinion that Internet can be used to circulate innovations easily. More so, all the respondents believed that giving attention to ICT training for extension agents will not only enhance their ability to use the Internet for sourcing and dissemination of innovation but also get relevant materials and new findings. Furthermore, 92.5\% of the respondents perceived the use of Internet as a source of motivation to both the extension agents and the farmers thereby promoting learning. Mojave (2006) opined that a lot of benefits can be derived from Internet (World Wide Web) usage among which are: quick access to information, delivery of news, access to worldwide visibility/readership of information. 


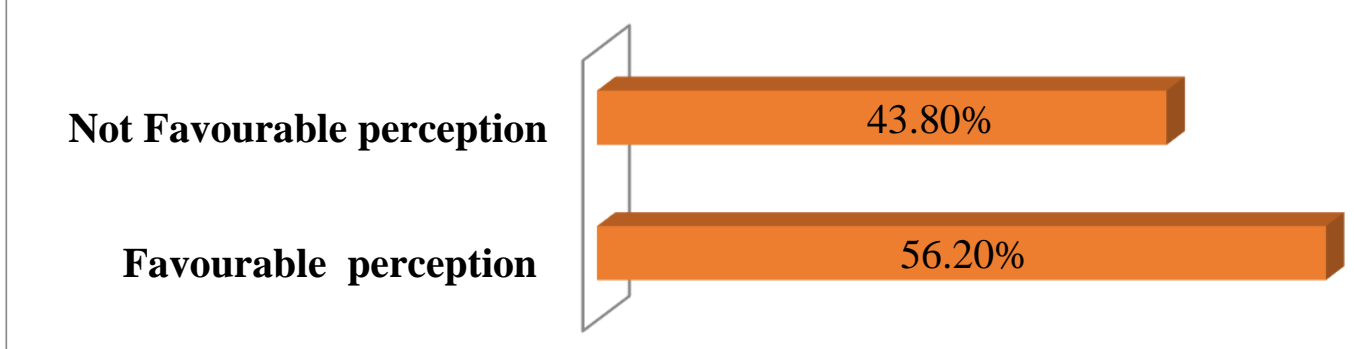

Figure 3: Extension agents' perception of the use of Internet for innovation management

Table 4: Extension agents' perception on the use of Internet in Oyo State Variables Mean SD

Internet helps in sourcing of innovation

The use of Internet can be used to circulate innovations easily

ICT training for extension agents will enhance their ability to use Internet for sourcing and dissemination of innovation

Internet is a means of getting relevant materials and new findings

The use of Internet is a source of motivation to both the extension agents and the farmers thereby promoting learning

Sourcing for innovation through the Internet is not helpful to the 4.04 extension agent

Large numbers of farmers fail to adopt innovations disseminated by 2.68 extension agent due to the use of Internet Internet coverage is readily available in areas extension agent 2.80 disseminates

Getting relevant materials for learning purpose cannot be achieved via
Internet

$4.60 \quad 0.49$

$4.29 \quad 1.11$

$4.41 \quad 0.49$

$4.48 \quad 0.50$

$4.38 \quad 0.83$ agents does not promote learning

\section{Challenges Associated with the Use of Internet}

Table 5 shows the challenges which the extension agents faced when sourcing and disseminating information through the use of Internet. It was revealed that majority $(93.8 \%)$ of the respondent's experience network failure when sourcing for innovations. More so, network congestion and unstable power supply were another challenges faced as reported by $90 \%$ of the respondents. The findings pointed out that many of the respondents faced with the problem of network failure, congestion and power supply. If the extension agents are constrained by these challenges, then it might be difficult to effectively use the Internet. This corroborates the finding of Fadiji (2011) who opined that network issues, funds for accessing the Internet as well as epileptic power supply were the major challenges faced by extension 
Creative commons User License: CC BY-NC-ND

Abstracted by: EBSCOhost, Electronic Journals Service (EJS),

Google Scholar, Directory of Open Access Journals (DOAJ),

Journal Seek, Scientific Commons,

Food and Agricultural Organization (FAO), andCABI
Journal of Agricultural Extension

Vol. 20 (1) June, 2016

ISSN(e): 24086851; ISSN(Print); 1119944X

http://journal.aesonnigeria.org

http://www.ajol.info/index.php/iae

Email: editorinchief@aesonnigeria.org

Also, high cost of Internet (85\%) and payment to access useful materials online $(87.5 \%)$ were pointed out by many of the respondents. The high cost of subscription for the Internet could affect the rate and extent that the extension agent will use the Internet. Even when they use Internet, they might not be able to access certain relevant information because of the restriction on them which require payment and that could discourage the use of Internet for innovation management among extension agents. Zainab et al., (2008) also identified the following problems associated with ICT use: frequent power failure and lack of alternative power supply, system difficulties operation, inadequate finance for procurement and maintenance of ICT facilities.

Table 6: Distribution of extension agents based on challenges faced in the use of Internet

\begin{tabular}{ll}
\hline Statements & $\%$ \\
\hline Network failure when sourcing for innovations & 93.8 \\
High cost of Internet affects the rate at which innovation is sourced & 85.0 \\
Low bandwidth in the vicinity affects the rate Internet can be accessed & 71.2 \\
Network congestion & 90.0 \\
Unstable power supply & 90.0 \\
Overload of not relevant but useful information & 46.2 \\
Internet facilities are not readily available in your location & 50.0 \\
Payment to access useful materials online & 87.5 \\
Undesirable content & 48.8 \\
\hline
\end{tabular}

Furthermore, less than fifty percent of the respondents indicated that there is too many information on the issue they are sourcing but many of them might not be directly relevant to the subject matter. Time spent to digress and harness information while browsing can consume more data use in browsing and that could discourage the use of the Internet. In the same vein, $(48.8 \%)$ of the respondent stated that undesirable content was another challenge they faced while using the Internet to source for innovation

\section{Relationship between the Extent of Use of Internet for Innovation Management by Extension Agents and their Perception of Internet Use}

Entries in Table 6 show that there is a significant relationship $(r=0.231 p \leq 0.05)$ between the extent of use of Internet and extension agents' perception of Internet use in innovation management. This implies that the more extension agents use Internet to source and disseminate innovation, the better their perception of the use of Internet in innovation management. The extension agents' favourable perception could influence their disposition and acceptance of the Internet for innovation management. The use of Internet for sourcing and disseminating of agricultural information is faster, versatile and could facilitate the transformation of agriculture via 
Creative commons User License: CC BY-NC-ND Abstracted by: EBSCOhost, Electronic Journals Service (EJS), Google Scholar, Directory of Open Access Journals (DOAJ), Journal Seek, Scientific Commons,

Food and Agricultural Organization (FAO), andCABI
Journal of Agricultural Extension Vol. 20 (1) June, 2016

ISSN(e): 24086851; ISSN(Print); 1119944X http://journal.aesonnigeria.org http://www.ajol.info/index.php/iae Email: editorinchief@aesonnigeria.org

transfer and uptake of a new idea. The result also shows that the two variables tested were positively correlated, which indicate that as the use of Internet by the extension agents' increases, the perception of the Internet uses for innovation management also increases in the same direction. The extension agent that uses Internet extensively is likely to have a favourable perception of its use in innovation management. Therefore, it is important to encourage extension agents in the use of Internet extensively by providing needed facilities required for internet surfing and helping them to overcome constraints associated with the use of the internet.

Table 6: Relationship between the extension agent's extent of use of Internet and perception of the use of Internet.

\begin{tabular}{ll}
\hline Variables & $\mathbf{r}$ \\
\hline Extent of Internet use and $0.231^{*}$ \\
perception of Internet for innovation \\
management
\end{tabular}

$\mathrm{P} \leq 0.05$

Source: Field survey, 2015.

\section{Conclusion and Recommendations}

The study concludes that extension agents in the study area are average users of Internet for innovation sourcing and dissemination. Mobile phones are mostly used by extension agents to access the Internet. The extent of Internet use is related to the perception of the extension agent toward it. Extension agencies should create awareness and organize in-service training for the staff on skill acquisition and importance of Internet use in sourcing and disseminating innovation. This will encourage extension agents to increase their extent of Internet use. It is necessary that access to Internet facilities be provided with other supporting amenities such as a constant supply of electricity, regular upgrading of Internet skills, software and hardware. This could re-orientate and prompt extension agents' interest in the better use of the Internet.

\section{References}

Adetumbi S. I., Olaniyi O. A. \& Adewale J. G. (2013). Assessment of use of selected information communication technologies (ICTs) for extension service delivery: Implication for agricultural development in Nigeria International Journal of Agricultural Management \& Development, 3(2), 131-139.

Aina, L. O. (2004). Decision makers and agricultural information in Africa the potential role of the Internet. IAALD Quarterly Bulletin, XLIV 96-99.

Aker, J. C. (2010). Dial 'A' for agriculuture: Using Information and Communication Technologies for Agricultural Extension in Developing Countries. Tuft University, Economics Department and Fletcher School, Medford MA02155

Ajayi A.O. (2013). Assessment of agricultural extension agents' knowledge and attitude towards agricultural insurance in Osun State, Nigeria. Journal of Agricultural Science and Applications 2(3), 143 - 150. 
Danladi, E. N., Gajare, H. J., Jarumi, M.\& Okonjie, M. (2008). Amana social studies for junior secondary schools (Book 2). Universal Basic

Education Edition, P. 40.

Duggan, M., \& Smith, A., (2013). Cell Internet use 2013. Retrieved from: http://www.pewinternet.org/2013/09/16/cell-internet-use-2013/

Ezeh A. N 2013. Extension agent's access and utilization of information and communication technology (ICT) in extension service delivery in South East Nigeria. Journal of Agricultural Extension and Rural Development. 5(11), 266276

Fadiji, T.O. (2011). Factors influencing usage of Information and Communication Technologies among village extension agents in three selected States Of NorthWest, Nigeria (Doctoral dissertation)

Jones M. J., Doll, D. \& Taylor, O. (2014). Extension must adopt mobile-Friendly websites Journal of Extension 52 (6) Available: http://www.joe.org/joe/2014dec.

Mojaye, E. M. (2006). Patterns of utilization of the internet and the World Wide Web by Nigerian Newspapers. The Nigerian Journal of Communications, 4(1\&2), 157- 163.

Mungo, A.\& Vermeulen, M. (2011). Let's talk about the use of ICTs in African agriculture. Farming Matters (March, 2011 issue):18-20.

National Population Commission. (2007).National Population Census Bulletin. Nigeria NPC.

Salau, E.S. \& Saingbe, N.D. (2008). Access and utilization of Information and Communication Technologies (ICTs) among agricultural researchers and extension workers in selected Institutions in Nasarawa State of Nigeria. PAT 4(2), 1-11. Accessed on July 22nd 2012.Retrieved from: http://www.patnsukjournal.com/currentissue.

Pew Research (2014). Mobile technology fact Sheet. Retrieved from: http://www.pewinternet.org/fact-sheets/mobile-technology-fact-sheet/

Saravanan, R. (Ed.). (2008). Agricultural extension: worldwide innovations. New India Publishing Agency (NIPA), New Delhi.

Umar, S., Musa, M. W., Olayemi, Y. T., Suleima R., 2015, Awareness and use of Information and Communication Technologies among extension agents in Kaduna State of Nigeria. Journal of Agricultural Extension 19(1), $66-76$.

Whitworth, A. (2009). Teaching information literacy within a relational frame: The media and information literacy course at Manchester. Journal of Information Literacy, 3(2), 25-38. doi: 10.11645/3.2.209

Zainab, M. Abdullahi, A. \& Haruna, I. (2003). Utilization of Information and Communication Technology (ICT) for information service delivery in university libraries in Adamawa State. The Information Technologist, 5(2):24- 30 . 